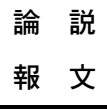

\title{
POPs 関連物質の加熱挙動に関する研究
}

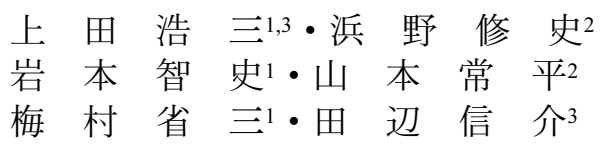

\section{Experimental Thermal Destruction of Persistent Organic Pollutants (POPs)}

\author{
Kozo UEDA ${ }^{1,3}$, Shuji HAMANO², Satoshi IWAMOTO ${ }^{1}$, Tunehira YAMAMOTO², \\ Shozo UMEMURA ${ }^{1}$ and Shinsuke TANABE ${ }^{3}$
}

\author{
${ }^{1}$ Hitachi Zosen Corporation, Engineering Division, Osaka 559-8559, Japan \\ ${ }^{2}$ Hitachi Zosen Corporation, Business Promotion \& Product Development Center, Osaka 551-0022, Japan \\ ${ }^{3}$ Center for Marine Environmental Studies (CMES), Ehime University Ehime 790-8577, Japan
}

\begin{abstract}
In Japan, large quantities of pesticides are stockpiled in many locations. The Japanese government aspires that these pesticides should be regulated by treating them as per the regulations of the Stockholm Convention which came into effect from the year 2004, controlling twelve persistent organic pollutants (POPs). Therefore, it has become mandatory to develop technologies that can effectively destroy these stockpiled pesticides safely and effectively. Having this in mind, in this study, the removal and elimination efficiency of DDTs, aldrin and BHC (HCHs) was investigated heating mixed samples of these pesticides in a tubular furnace coupled with a secondary combustion chamber, in presence of air or nitrogen. We observed no difference in the volatilization temperatures of these pesticides when the samples were heat-treated either under nitrogen or air. When the sample was heated to $600^{\circ} \mathrm{C}$ under a nitrogen atmosphere, an increase in the ratio of DDE in total DDTs was observed. About $90 \%$ of the aldrin was destroyed. BHC was volatilized almost completely at this temperature but did not disintegrate at all. A high removal rate was observed for all the chemicals when the flue gas from the tubular furnace was heated to $1,100^{\circ} \mathrm{C}$ in the secondary combustion chamber. However, the volatilization rate of $\mathrm{BHC}(\mathrm{HCHs})$ decreased when the oxygen concentration in the secondary combustion chamber was lowered. This study proves the effectiveness of a system designed to vaporize pesticides through heating in a furnace at high temperature followed by combustion of the flue gas.
\end{abstract}

Key words: POPs, Thermal Destruction, DDTs, Aldron, BHC

\section{1. 緒言}

残留性有機污染物質 (POPs: Persistent Organic Pollutants）は，ひとたび自然界へ放出されると分解され ずに残留しやすく，食物連鎖等を通じて生態内に蓄積し やすい性質を有している1。 またその物理的性状から移 動・拡散が起こりやすく, 地球規模の污染を引き起こす といわれている2。これら POPsによる污染を防止する目 的で, 2001 年 5 月にストックホルムで行われた外交会議 に扣いて,「残留性有機污染物質に関するストックホルム 条約」が採択され, 2004 年にはフランスの批准により規

キーワード：ポップス, 熱分解処理, ディーディー ティー，アルドリン，ビーエイチシー

1 日立造船株式会社エンジニアリング本部

2 日立造船株式会社事業・製品開発センター

3 愛媛大学沿岸環境科学研究センター

平成 18 年 3 月 4 日受理
定国数に達し, 条約が発効された（2005 年 5 月現在, 我 が国を含む 100 力国拈よび EC が締結)。条約には各国が とるべき対策として POPsを含むストックパイル（在庫） や廃棄物の適正管理および処理が定められている。わが 国に拈いても埋設廃農薬が約 3,680トン (1カ所 3 トン以 上の保管数量）存在すると報告されて打り ${ }^{3)}$, 対策が急 がれている。これらの埋設廃農薬を適正に処理すること を目的として，環境省は平成 13 年度から「POPs 農薬無 害化処理技術実証等検討調査」を進めているものの, 国 内に打ける埋設廃農薬を対象とした無害化処理に関する 研究報告は未だ少なく, 無害化処理もほとんど進められ ていないのが現状である。著者らはこれまでに POPs 指 定物質であるダイオキシン類で活染された土壌を無害化 処理するプロセスを開発して抢り, ごみ焼却炉跡地の実 污染現場での無害化処理工事の実績を有している。また その技術を応用して河川底質中のダイオキシン類無害化 実証試験などを行ってきた 4,5)。これらの処理技術は500- 
$700^{\circ} \mathrm{C}$ の中温域での加熱による窒素雾囲気下の還元脱塩 素化方式と二次燃焼方式を主体とした技術である。本研 究ではこれらのプロセスがダイオキシン類と同様の有機 塩素化合物である廃農薬の処理に応用できると考光, 検 証を行った。対象とした物質は POPs 条約で指定されて いる DDT（メオバール D 粒剂）とアルドリン粉剂, 条 約指定物質ではないが国内では製造・販売が禁止されて いる BHC 粒剤の 3 種について, 熱的特性試験, 加熱試 験および加熱の際に発生する排ガスの二次燃焼試験を行 い, 加熱脱着と二次燃焼を組み合わせたシステムの有効 性を確認したので報告する。

\section{2. 実験方法}

\section{1 実験対象試料}

実験にはA 自治体が保管していた廃農薬を分取したも のを試料として使用した。対象物質は殺虫剂として使用 されていたメオバール D 粒剤 (DDT 含有) とアルドリ ン粉剤を選定した。またPOPs条約物質ではないが, OECD (経済協力開発機構) で削減や廃絶が議論されて扣り, 国 内では既に製造・使用禁止になっている BHC 粒剂も供 試した。な抗これら実験に用いた物質は, 平成 13 年 12 月に農林水産省が発表した「埋設農薬の実態調査の結果 について」の中で埋設量が多い上位 3 物質 (BHC : 49\%, DDT : 26\%，アルドリン：1.4\%）である。

\section{2 試料の熱的特性試験}

廃農薬は長期保管による製造時の物性変化が予想され る。製造時の物性は製造者への問い合わせや過去の資料 を調査することで把握できるが，これらの情報で得た データのみで処理条件の設定や加熱処理装置を設計する ことはきわめて危険である。そこで実験に用いる試料が 特異的に変化したものではなく, 埋設農薬を代表する試 料として実験に適したものであることを判断するため に，熱的特性試験を行い変化の有無を調べた。熱的特性 の把握には，TG/DTA（示差熱・重量同時測定）測定装 置を用いた。測定装置の設定条件は昇温速度を $10^{\circ} \mathrm{C} /$ 分 とし, 空気中での加熱と窒素中での加熱をそれぞれ実施 した。な报 TG/DTA 測定には, 示差熱/ 熱重量同時測定 装置（形式：TG/DTA220, セイコ一電子工業（株））を 用いた。

\section{3 加熱試験}

加熱処理後の試料中に残存する対象物質の濃度と気化 割合を調べるために，管状炉を用いた加熱試験を実施し た。実験にはメオバール D 粒剂, アルドリン粉剂, BHC 粒剂扣よび 7 号ケイ砂（鹿島砂）を混合した試料を用い た。試料の混合比率は Table 1 に示した。加熱試験に使 用した装置 (Fig. 1) は, 電気ヒーターによる加熱方式の
Table 1 Weight percentage and total weight of sample

\begin{tabular}{lcc}
\hline & $\begin{array}{c}\text { Composition } \\
\text { ratio }\end{array}$ & $\begin{array}{c}\text { Total Weight } \\
\text { (wet) }\end{array}$ \\
\hline Silica sand & $50 \%$ & \\
DDT included pesticide & $20 \%$ & $20 \mathrm{~g}$ \\
Aldrin included pesticide & $20 \%$ & \\
BHC included pesticide & $10 \%$ & \\
\hline
\end{tabular}

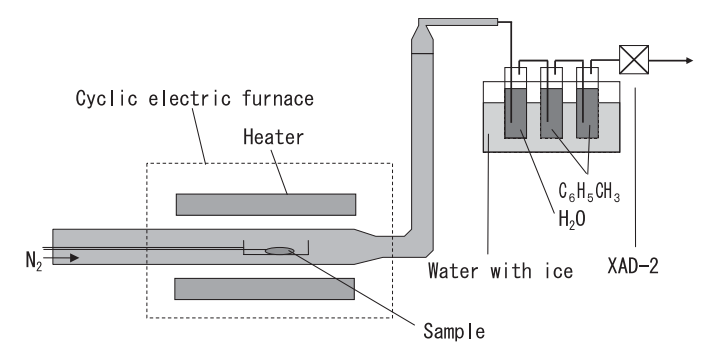

Fig. 1 Schematic diagram of the experimental heating system

管状炉と加熱時に発生するガスを吸収させるインピン ジャー（1 段目：水， 2 段目／3段目：トルエン ), イン ピンジャーからのガス抜けを考慮して樹脂吸着層（アン バーライト XAD-2 : オルガノ (株), $10 \mathrm{ml}$ )を取り付け た構成とした。常温状態の管状炉内に $20 \mathrm{~g}$ の試料を入れ た耐熱ガラス容器を挿入し, $10^{\circ} \mathrm{C} /$ 分の割合で所定温度 まで昇温させ，加熱中は管状炉内へパージガスとして窒 素を $0.5 \mathrm{LN} /$ 分で流入させた。所定温度に到達した後は 20 分間保持し, 管状炉内からガラス容器を抜き出してダイ オキシン類の再生を防止するために冷風により速やかに 冷却した6)。な打本実験では加熱中の試料温度を正確に 測定するために, 熱電対を試料内の 3 箇所に挿入して連 続監視した (Fig. 2)。加熱温度は $500^{\circ} \mathrm{C}$ (Run T-1), $600^{\circ} \mathrm{C}$ (Run T-2), $700^{\circ} \mathrm{C}$ (Run T-3) の 3 条件とした。各実験の 終了後には加熱処理した残椬と Run T-2 の加熱に伴い発 生したガスの吸収液および樹脂吸着層を分析に供した。 ガス系統ライン中のガラス管内部はトルエンで洗い込 み, 吸収液, 樹脂吸着層と共に分析に供した。残椬は BHC を各 Run で測定し, DDT は Run T-2, Run T-3 で, アルドリンはRun T-2 $\left(600^{\circ} \mathrm{C}\right.$ 加熱）のみを測定した。

\section{4 二次燃焼試験}

廃農薬を管状炉で加熱処理した場合，加熱炉内で分解 されずに残った農薬成分は発生するガス中へ移行するこ とが予想される。これらの残存物質を分解するために, 2.2 の加熱試験で使用した装置に二次燃焼炉を追設して 発生排ガスの二次燃焼試験を実施した。

二次燃焼炉の炉本体には内径 $20 \mathrm{~mm}$, 厚さ $3 \mathrm{~mm}$ の石 英管を用いた。石英管内を流れるガスの覺拌と接触燃焼 を目的として, 内部には充填材を入れた。充填物には石 


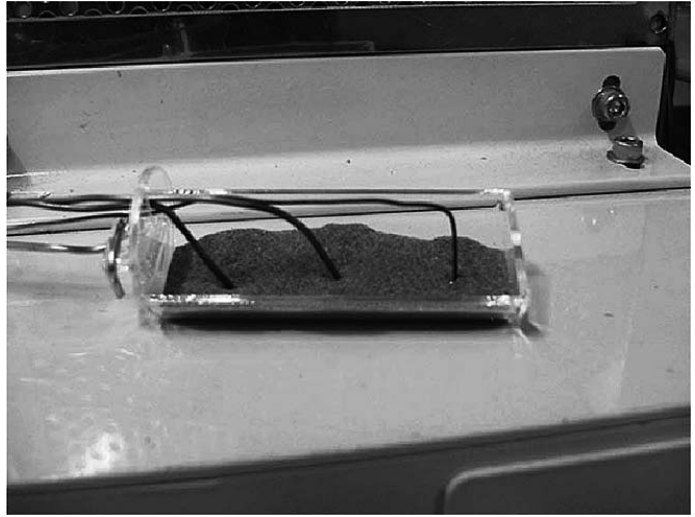

Fig. 2 Experimental set-up with three thermocouples used to measure the average temperature of the mixed pesticide sample

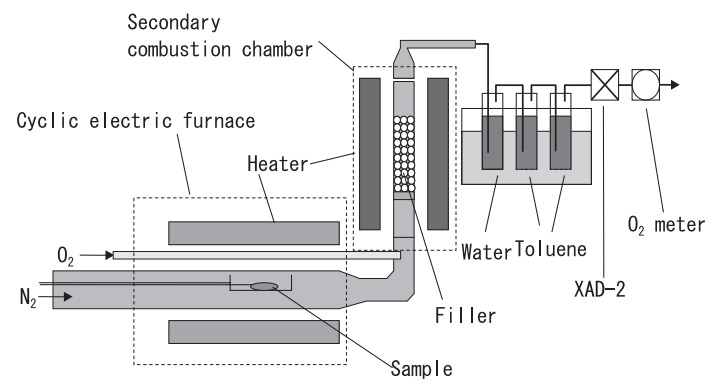

Fig. 3 Schematic diagram of heating and gas oxidation test system

英パイプ（ $\phi 4 \mathrm{~mm} \times \mathrm{L} 4 \mathrm{~mm} \times \mathrm{t} 1 \mathrm{~mm})$ を使用し，二次燃焼 炉（石英菅）の内部に約 700 個充填した。石英菅の外周 を電気ヒータで覆い, 間接的に内部のガスを加熱した。 また管状炉と石英菅の間にはガス注入ラインを設け，ガ ス中の未燃物質を燃焼させるための酸素を注入した。二 次燃焼炉から排出されるガスは加熱試験と同様にインピ ンジャー（1段目：水，2段目／３段目：トルエン）と樹 脂吸着層 (アンバーライト XAD-2:オルガノ(株), $10 \mathrm{ml}$ ) を通過させ，樹脂吸着塔の後流に設置した酸素濃度計に より排ガス中の酸素濃度を連続測定した。実験装置つ
ローを Fig. 3 示す。

試料は，加熱試験と同じものを用いた（Table 1）。管 状炉内には，パージガスとして窒素を $0.5 \mathrm{LN} / \mathrm{min}$. 注入し つつ試料を $600^{\circ} \mathrm{C}$ で加熱した。二次燃焼炉は内部の温度 を $1,100^{\circ} \mathrm{C}$ とし, 二次燃焼炉の前段から $0.09 \mathrm{~L}_{\mathrm{N}} / \mathrm{min} .\left(\mathrm{O}_{2}\right.$ : $15.3 \%), 0.14 \mathrm{~L}_{\mathrm{N}} / \mathrm{min} .\left(\mathrm{O}_{2}: 21.8 \%\right)$ および $0.19 \mathrm{~L}_{\mathrm{N}} / \mathrm{min} .\left(\mathrm{O}_{2}\right.$ : $27.5 \%$ )の酸素を注入する 3 条件と, 酸素注入量を $0.14 \mathrm{~L}_{\mathrm{N}} /$ min. に固定し加熱温度を $800^{\circ} \mathrm{C}, 900^{\circ} \mathrm{C} 。 1,100^{\circ} \mathrm{C}$ に変化 させた実験の計 6 条件で実施した。各実験条件を Table 2 に示す。

\section{3. 結果と考察}

\section{1 試料の熱的特性}

メオバール D 粒剤とアルドリン粉剤および $\mathrm{BHC}$ 粒剂 の TG/DTA 測定結果を, Fig. 4 ～Fig. 9 にそれぞれ示す。 な敃図中の横軸は測定対象物の加熱温度を示し, 縦軸は TG（熱重量測定 thermogravimetry：試料の重量変化を連 続的に測定したもの。\%は元試料に対する重量減の割合） と, DTG (differential TG 微分熱重量分析 : TG 曲線を微 分したもの）扣よび TA（示差熱分析 differential thermal analysis : 試料と基準試料[ $\alpha$-アルミナ〕の温度差を熱電 対の熱起電力）を示している。DTG曲線のピークは, 測 定対象物の重量が急激に減少している温度範囲である。 すなわちこのピークは, 測定対象物が気化している温度 域であることを示している。

TG/DTA 測定結果をみると，各試料の主な気化温度は $90^{\circ} \mathrm{C}$ から $230^{\circ} \mathrm{C}$ の範囲内にあることがわかる。各試料と もに $700^{\circ} \mathrm{C}$ までの揮発分が $1 \sim 3 \%$ 程度存在しているが, これは農薬を造粒する工程で必要なバインダー材等が影 響を及ぼしたと考えられる。加熱中のガス䨌囲気の違い による影響をみたところ, 空気と窒素の TG/DTA 曲線の 変化はほとんどなく，気化温度は酸素の有無に大きな影 響を与えないことがわかった。

試料毎の主な気化温度の範囲をみるとメオバール D 粒 剂は $160 \sim 230^{\circ} \mathrm{C}$ であり,アルドリン粉剤は $100 \sim 200^{\circ} \mathrm{C}$, $\mathrm{BHC}$ 粒剤は $90 \sim 230^{\circ} \mathrm{C}$ であった。環境省が公表してい

Table 2 Experimental conditions of heating temperature at cyclic electric furnace and secondary combustion chamber

\begin{tabular}{rcccc}
\hline \multirow{2}{*}{ Run } & \multicolumn{1}{c}{ Heaing temp. at C.E.F. ${ }^{1} 1$} & Heaing temp. at S.C.C. $\aleph_{2}$ & Flow rate of $\mathrm{N}_{2}$ & Flow rate of $\mathrm{O}_{2}$ \\
\cline { 2 - 5 } & ${ }^{\circ} \mathrm{C}$ & ${ }^{\circ} \mathrm{C}$ & $\mathrm{L}_{\mathrm{N}} / \mathrm{min}$. & $\mathrm{L}_{\mathrm{N}} / \mathrm{min}$. \\
\hline Run S-1 & 600 & 800 & 0.5 & 0.14 \\
Run S-2 & 600 & 900 & 0.5 & 0.14 \\
Run S-3 & 600 & 1,100 & 0.5 & 0.09 \\
Run S-4 & 600 & 1,100 & 0.5 & 0.14 \\
Run S-5 & 600 & 1,100 & 0.5 & 0.19 \\
\hline
\end{tabular}

※1 C.E.F.: means Cyclic electric furnace

${ }^{2}$ S.C.C.: means Secondary combustion chamber 


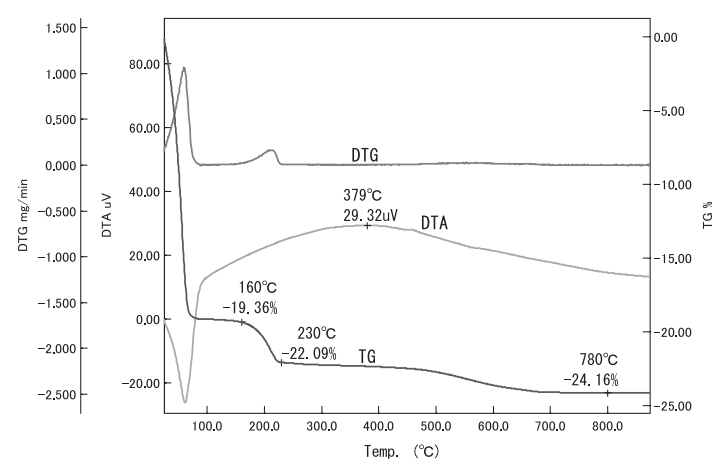

Fig. 4 TG and DTA curves of a granule including DDT in air

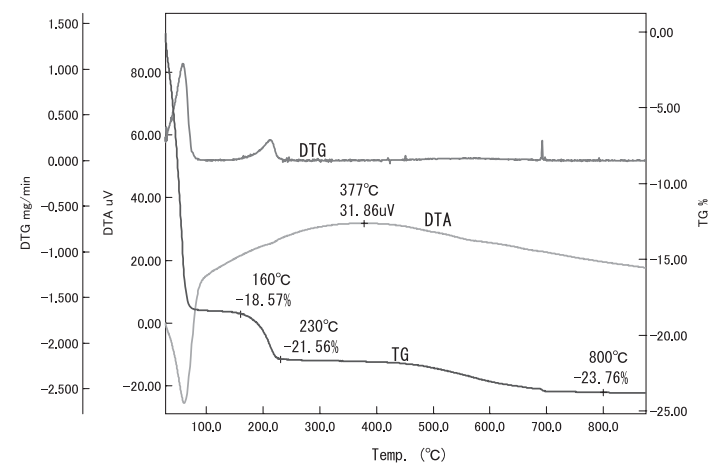

Fig. 5 TG and DTA curves of a granule including DDT in nitrogen

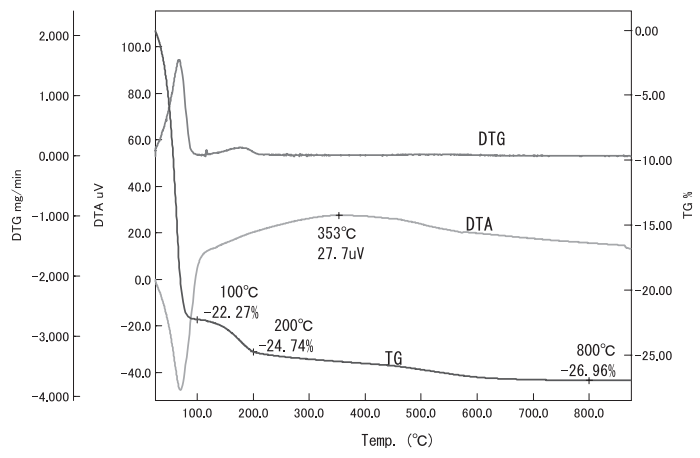

Fig. 6 TG and DTA curves of a powder including Aldrin in air

る「POPs 対策検討会（第 2 回），参考資料 8-2「POPs 有 害性等データシート」拈よび神奈川県が発表している化 学物質安全情報提供システム（Kis-NET）のデータでの 各物質の融点と沸点の值と本実験結果を比較したとこ ろ，大差は認められなかった（Table 3）。よって本実験 に用いた試料 (メオバール D 粉剂, アルドリン粉剤, BHC 粒剂）は純成分と比較して特異な変化はして抢らず，代 表的な埋設保管農薬であると判断でき, 実験試料として

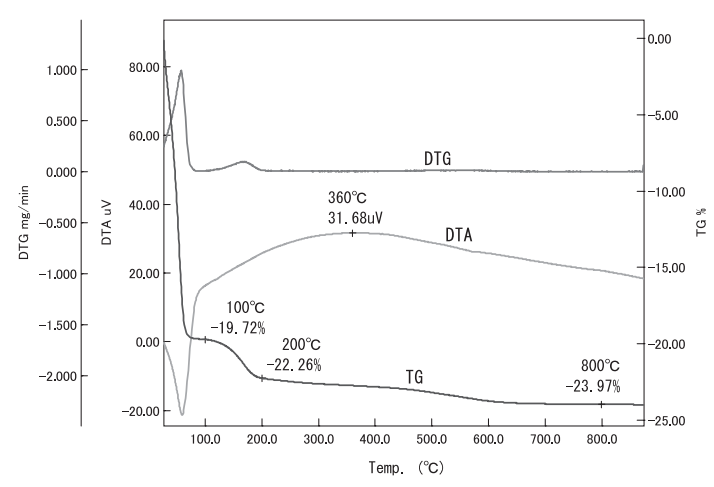

Fig. 7 TG and DTA curves of a powder including Aldrin in nitrogen

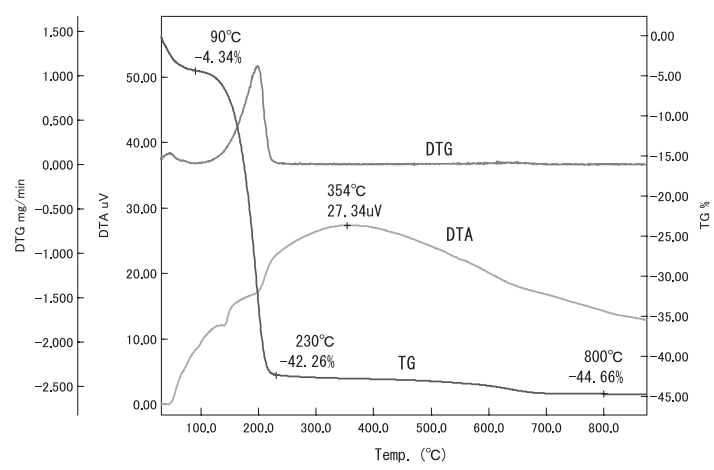

Fig. 8 TG and DTA curves of a granule including BHC in Air

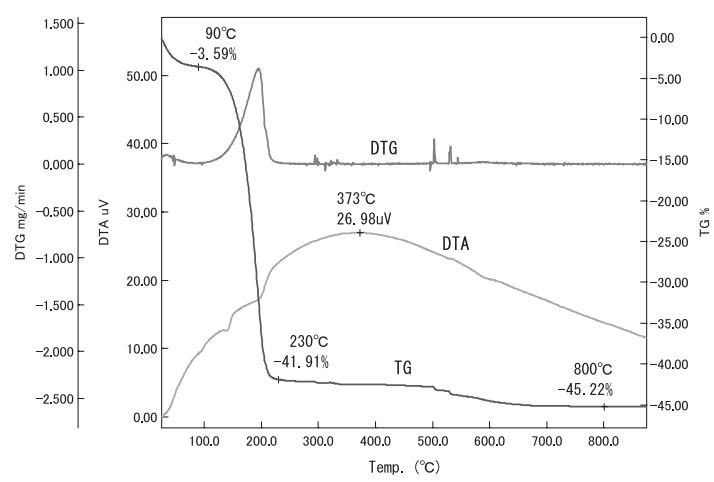

Fig. 9 TG and DTA curves of a granule including BHC in nitrogen

問題ないことが確認できた。

\section{2 加熱試験結果}

加熱処理した各試料中の対象物質濃度と除去率抏よび Run T-2 に抢いて排ガス側へ移行した対象物量（処理前 の試料 $1 \mathrm{~g}$ に対するガス側で捕集した物質量：以降，ガ ス残存量と称す）扣よびその割合を Table 4 に示す。加 熱処理前の各試料中の対象物質濃度はそれぞれDDT 
上田 浩三・浜野 修史・岩本 智史 - 山本 常平・梅村 省三・田辺 信介

Table 3 Start and end point of volatilization of sample

\begin{tabular}{|c|c|c|c|c|c|}
\hline & Purge gas & $\begin{array}{l}\text { Starting point of } \\
\text { volatilization }\end{array}$ & $\begin{array}{l}\text { End point of } \\
\text { volatilization }\end{array}$ & Melting point & Boiling point \\
\hline \multirow[t]{2}{*}{ DDT } & Air & 160 & 230 & \multirow[t]{2}{*}{$108 \sim 109 ※ 1$} & \multirow[t]{2}{*}{$260 ※ 1$} \\
\hline & N2 & 160 & 230 & & \\
\hline \multirow[t]{2}{*}{ Aldrin } & Air & 100 & 200 & \multirow[t]{2}{*}{$101 \sim 105 ※ 1$} & \multirow[t]{2}{*}{$145 * 1$} \\
\hline & $\mathrm{N} 2$ & 100 & 200 & & \\
\hline \multirow[t]{2}{*}{$\mathrm{BHC}$} & Air & 90 & 230 & \multirow[t]{2}{*}{$113 \approx 1$} & \multirow[t]{2}{*}{$200 ※ 2$} \\
\hline & N2 & 90 & 230 & & \\
\hline
\end{tabular}

※1 Kis-NET (Kanagawa prefectural office report)

$\left({ }^{\circ} \mathrm{C}\right)$

$\aleph^{2}$ Reported by Ministry of the Environment

Table 4 Analytical results for pre-and post-heating sample and gas sample at Run T-2

\begin{tabular}{|c|c|c|c|c|c|c|}
\hline & & Sample & Run T-1 & Run T-2 & Run T-3 & $\begin{array}{c}\text { Run T-2 } \\
\text { (Gas Sample) }\end{array}$ \\
\hline \multicolumn{2}{|c|}{ Heating Temp. $\left({ }^{\circ} \mathrm{C}\right)$} & - & 500 & 600 & 700 & 600 \\
\hline \multirow{7}{*}{ 穴 } & $o, p^{\prime}-\mathrm{DDT}$ & 970 & - & N.D. & N.D. & $11.2(1.2 \%)$ \\
\hline & $p, p^{\prime}-\mathrm{DDT}$ & 3,900 & - & N.D. & N.D. & $33.1(0.8 \%)$ \\
\hline & $o, p^{\prime}-\mathrm{DDE}$ & N.D. & - & $\begin{array}{c}0.0028 \\
(1,020 \% *)\end{array}$ & N.D. & $\begin{array}{c}507 \\
\left(203 \times 10^{60 \% *}\right)\end{array}$ \\
\hline & $p, p^{\prime}-\mathrm{DDE}$ & 4.8 & - & $\begin{array}{c}0.0096 \\
(99.8 \%)\end{array}$ & N.D. & $\begin{array}{c}2,232 \\
(46,500 \%)\end{array}$ \\
\hline & $o, p^{\prime}-\mathrm{DDD}$ & 44 & - & N.D. & N.D. & $1.2(2.7 \%)$ \\
\hline & $p, p^{\prime}-\mathrm{DDD}$ & 58 & - & N.D. & N.D. & $1.0(1.8 \%)$ \\
\hline & Total & 4,980 & - & $\begin{array}{c}0.0124 \\
(99.9998 \%)\end{array}$ & N.D. & $\begin{array}{c}2,785 \\
(56.0 \%)\end{array}$ \\
\hline \multicolumn{2}{|c|}{ Aldrin } & 5,000 & - & N.D. & - & $478(9.6 \%)$ \\
\hline \multirow{5}{*}{$\stackrel{\cup}{\infty}$} & $\alpha$ & 18,000 & $\begin{array}{c}0.031 \\
(99.9998 \%)\end{array}$ & $\begin{array}{c}0.019 \\
(99.9998 \%)\end{array}$ & $\begin{array}{c}0.0002 \\
(99.99999 \%)\end{array}$ & $\begin{array}{l}22,590 \\
(126 \%)\end{array}$ \\
\hline & $\beta$ & 2,400 & $\begin{array}{c}0.004 \\
(99.9998 \%)\end{array}$ & $\begin{array}{c}0.004 \\
(99.9998 \%)\end{array}$ & N.D. & $\begin{array}{c}2,161 \\
(90.0 \%)\end{array}$ \\
\hline & $\gamma$ & 4,100 & $\begin{array}{c}0.012 \\
(99.9997 \%)\end{array}$ & $\begin{array}{c}0.0015 \\
(99.99996 \%)\end{array}$ & N.D. & $\begin{array}{c}3,532 \\
(86.1 \%)\end{array}$ \\
\hline & $\delta$ & 1,700 & $\begin{array}{c}0.017 \\
(99.9990 \%)\end{array}$ & $\begin{array}{c}0.0051 \\
(99.9997 \%)\end{array}$ & N.D. & $\begin{array}{c}1,956 \\
(108.7 \%)\end{array}$ \\
\hline & Total & 26,200 & $\begin{array}{c}0.064 \\
(99.9997 \%)\end{array}$ & $\begin{array}{c}0.030 \\
(99.9998 \%)\end{array}$ & $\begin{array}{c}0.0002 \\
(99.999999 \%)\end{array}$ & $\begin{array}{c}30,328 \\
(115.8 \%)\end{array}$ \\
\hline
\end{tabular}

* Calculated with a half of the minimum limit of determination $(\mu \mathrm{g} / \mathrm{g})$

$(4,980 \mu \mathrm{g} / \mathrm{g})$, アルドリン $(5,000 \mu \mathrm{g} / \mathrm{g})$, BHC $(26,200 \mu \mathrm{g} /$ $\mathrm{g}(\gamma-\mathrm{BHC}: 4,100 \mu \mathrm{g} / \mathrm{g}))$ であった。環境省の報告7)では メオバール D 粒剤中の DDT 成分は約 $4 \sim 5 \%$, アルド リン粉剂中のアルドリン成分は $1.9 \sim 3.8 \%$, BHC 粒剤 中の $\gamma$-BHC 成分は $2 \sim 6 \%$ となっていることから, 作成 した混合試料の各物質濃度はオーダ一的に一致してお り，対象物質の成分についても埋設農薬を代表した試料 であることが確認された。各物質の挙動を以下に示す。

\subsubsection{DDT}

メオバール D 粒剂の DDT 成分 $\left(o, p^{\prime}-\mathrm{DDT}, p, p^{\prime}-\mathrm{DDT}\right.$, $o, p^{\prime}$-DDE, $p, p^{\prime}$-DDE, $o, p^{\prime}$-DDD, $p, p^{\prime}$-DDD を合わせて以 降 DDT〔Total〕と称す。）は，加熱処理前で $4,980 \mu \mathrm{g} / \mathrm{g}$

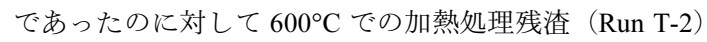

は $0.0124 \mu \mathrm{g} / \mathrm{g}$ であった。除去率は 99.999\%以上となり， DDT（Total）のほとんどは除去できていることが確認で き, $700^{\circ} \mathrm{C}$ の加熱（Run T-3）では定量下限值（0.0001 $\mu \mathrm{g} /$ g）以下となった。Run T-2 の処理残椬を成分ごとに調べ ると $o, p^{\prime}$-DDT, $p, p^{\prime}$-DDT, $o, p^{\prime}$-DDD および $p, p^{\prime}$-DDD は 加熱処理後の濃度が定量下限 $(0.0001 \mu \mathrm{g} / \mathrm{g})$ 以下となり, $o, p^{\prime}$-DDE, $p, p^{\prime}$-DDE は検出されたがその值は低いもので あった。一方ガス側へは DDT（Total）として約 56\%が 移行していた。なかでも $p, p^{\prime}$-DDE は, 処理前試料に対し て増加率が 465 倍ときわめて高い值を示した。また $o, p^{\prime}-$ DDE は初期試料では定量下限 $(0.0001 \mu \mathrm{g} / \mathrm{g})$ 以下であっ たにもかかわらず，ガス側からは $507 \mu \mathrm{g} / \mathrm{g}$ (ガス残存量) が検出された。これはメオバール D 粒剤を窒素雾囲気下 
で加熱したことによって，初期試料にはほとんど含まれ ていないDDE 異性体が生成されたことを示唆している。 この要因や経路については本実験では把握できず，今後 の検討課題としたい。

\subsection{2 アルドリン}

アルドリン粉剂中のアルドリン濃度は加熱処理前で $5,000 \mu \mathrm{g} / \mathrm{g}$ であったのに対し, 加熱処理後の残椬中濃度は 定量下限值 $(0.0001 \mu \mathrm{g} / \mathrm{g})$ 以下となった。よってアルド リンも DDT (Total) と同様に $600^{\circ} \mathrm{C}$ 程度の加熱で十分に 気化させることが可能であると判断された。またガス側 への移行は 1 割程度であり, 約 9 割が分解していた。こ の結果からアルドリンはDDT（Total）に比べて気化しや すく，分解もしやすい物質であることがわかった。

\subsubsection{BHC}

加熱処理前の BHC 粒剂中の BHC 異性体成分 ( $\alpha-\mathrm{BHC}$, $\beta$-BHC, $\gamma$-BHC， $\delta$-BHC を合わせて以降 BHC [Total]と 称す）の濃度が $26,200 \mu \mathrm{g} / \mathrm{g}$ であったのに対し, Run T-1 $\left(500^{\circ} \mathrm{C}\right)$ では $0.064 \mu \mathrm{g} / \mathrm{g}$, Run T-2 $\left(600^{\circ} \mathrm{C}\right)$ では $0.030 \mu \mathrm{g} /$ g, Run T-3 $\left(700^{\circ} \mathrm{C}\right)$ では $0.0002 \mu \mathrm{g} / \mathrm{g}$ となり, 加熱温度 の上昇に伴って除去率も上昇した。各異性体の除去率を みても全ての異性体に扔いて 99.999\%以上を満足して括 り, とくに除去困難な異性体は認められず， ほぼ均一に 除去されていた。処理前試料の含有量とガス残存量から 算出されるガス側への移行率をみると, BHC（Total）は $115.8 \%$ となり, 初期試料より増加した。増加の理由は明 らかではないが, POPs 関連物質であるダイオキシン類の 公定法に打ける微量分析では土 $30 \%$ の誤差が認められて 扣り, 使用機器や手法が類似した BHC 等でも十分に起 こりえる分析䛊差の範囲内と推察する。異性体をみても 処理前試料に対して若干の増減はあるものの, 大差はみ られなかった。この結果から加熱されることにより試料 中の BHC は気化しているが，その汪とんどは分解せず にガス側へ揮散していることが分かった。

以上の結果より, 窒素雲囲気下に打ける $500 \sim 600^{\circ} \mathrm{C}$ 程度の加熱処理によってアルドリンはほぼ全量が気化 し, DDT (Total), BHC (Total) ๖ 99.999\%以上, $700^{\circ} \mathrm{C}$ では 99.9999\%以上が気化していることから,これら物質 を除去できることが明らかとなった。またアルドリンは, 約 9 割が分解していることも把握できた。よってこれら の 3 物質を含んだ POPs 対象廃農薬を無害化処理する場 合は $700^{\circ} \mathrm{C}$ 以下の加熱によって十分に気化（脱着）する ことができ，気化したガスの処理が可能であれば処理シ ステムの構築が可能と考えられた。

\section{3 二次燃焼試験結果}

加熱試験の結果から，加熱過程で発生する気化ガスの 処理が必要と判断されたため, 二次燃焼炉を付設した装 置を用いて同様の加熱試験を行い，二次燃焼処理におけ
る各物質の挙動を調べた。加熱処理前の試料中各対象物 の濃度と二次燃焼炉後のガス残存量（試料 $1 \mathrm{~g}$ に対する 換算值) 抽よび二次燃焼炉出口ガスの酸素濃度 (最低值) を Table 5 に示す。

\subsubsection{DDT}

DDT (Total) は, 二次燃焼炉の温度が $800^{\circ} \mathrm{C}$ から $1,100^{\circ} \mathrm{C}$ に上昇寸るにつれてガス残存量の減少がみられた（Run S-1, Run S-2, Run S-4)。物質毎にみると加熱試験の際に ガス側で生成が見られた $o, p^{\prime}-\mathrm{DDE} と p, p^{\prime}-\mathrm{DDE}$ は, $1,100^{\circ} \mathrm{C}$ では定量下限值 $(0.00003 \mu \mathrm{g} / \mathrm{g})$ 以下となり, $p, p^{\prime}$-DDT の 又が検出された。この要因については不明であるが，検 出された濃度は低く, 初期濃度が他の異性体に比べてき わめて高いことから, 実験過程に抢ける二次污染の可能 性も考えられる。DDT (Total) としては加熱テストでガ ス側へ移行した量から換算して 99.9999\%以上の高い除 去率が得られて扣り，二次燃焼炉の十分な除去効果がみ られた。また二次燃焼炉への酸素供給量の違いによる残 存量は Run S-5 > Run S-3 > Run S-4 の順となり, Run S5 は余利酸素が多いにもかかわらずその残存量は多かっ た。除去率悪化の要因は不明であるが，悪化に寄与して いるのは $p, p^{\prime}$-DDT であり, この要因についても前述した 二次污染が疑われる。DDT（Total）の初期試料中含有量 に対する残存量（処理残椬中含有量に二次燃焼処理後の 排ガス中含有量を加えた数值) から算出される除去率 (以 降, 全体除去率と称す) は99.9997\%であり, 加熱温度を $700^{\circ} \mathrm{C}$ にした場合はより高い除去率が得られるものと予 想される。

\subsection{2 アルドリン}

アルドリンは，全ての実験に打いて定量下限值 $(0.00003 \mu \mathrm{g} / \mathrm{g})$ 以下となった。加熱試験ではガス側へ約 9.6\%移行が認められたが, これらも二次燃焼炉に打いて 分解されていることが確認できた。二次燃焼炉の温度が $900^{\circ} \mathrm{C}$ であってもガス濃度は定量下限值以下であり, 酸 素濃度にも大きく影響されないことから，アルドリンは DDT (Total) や BHC (Total) に比べて熱的安定性の低 いことがわかる。よってアルドリン単体を処理する場合, 炉内を $900^{\circ} \mathrm{C}$ 程度まで昇温すれば, 高い分解率が得られ るものと予想される。

\subsubsection{BHC}

$1,100^{\circ} \mathrm{C}$ での加熱の場合, BHC (Total) は供給する酸 素量の増加に伴ら二次燃焼炉出口ガス中の残存量の減少 がみられた（Run S-3, Run S-4, Run S-5）。加熱試験に抒 いて, $600^{\circ} \mathrm{C}$ の加熱では BHC（Total）はほとんど分解せ ず, ほぼ全量がガス側へ移行したことが確認されている。 よって二次燃焼炉に初期試料の全量が移行したと仮定し た場合，二次燃焼炉での分解率は最も酸素濃度が低い Run S-3 で 99.9997\%となり, Run S-4 では 99.9999\%, Run 
上田 浩三・浜野 修史・岩本 智史・山本 常平・梅村 省三・田辺 信介

Table 5 Analytical results for the pre-heating sample and conversion value of the substance which was sampled from flue gas for pre-heating sample

\begin{tabular}{|c|c|c|c|c|c|c|c|}
\hline & & Sample & Run S-1 & Run S-2 & Run S-3 & Run S-4 & Run S-5 \\
\hline & & & \multicolumn{5}{|c|}{ Heating Temp. $\left({ }^{\circ} \mathrm{C}\right)$} \\
\hline & & & $800^{\circ} \mathrm{C}$ & $900^{\circ} \mathrm{C}$ & $1,100^{\circ} \mathrm{C}$ & $1,100^{\circ} \mathrm{C}$ & $1,100^{\circ} \mathrm{C}$ \\
\hline & & & \multicolumn{5}{|c|}{ Oxygen injected quantity to the secondary combustion chamber $\left(\mathrm{L}_{\mathrm{n}} / \mathrm{min}\right.$.) } \\
\hline & & & 0.14 & 0.14 & 0.09 & 0.14 & 0.19 \\
\hline & & & \multicolumn{5}{|c|}{ Minimum oxygen concentration of flue gas at secondary combustion chamber (\%) } \\
\hline & & & 10.7 & 8.0 & 8.2 & 0.7 & 12.7 \\
\hline \multirow[t]{7}{*}{ DDT } & $o, p^{\prime}-\mathrm{DDT}$ & 970 & N.D. & N.D. & N.D. & N.D. & N.D. \\
\hline & $p, p^{\prime}$-DDT & 3,900 & 0.0001 & 0.00006 & 0.00004 & 0.00006 & 0.00031 \\
\hline & $o, p^{\prime}-\mathrm{DDE}$ & N.D. & N.D. & 0.00029 & 0.00003 & N.D. & N.D. \\
\hline & $p, p^{\prime}-\mathrm{DDE}$ & 4.8 & 0.00004 & 0.0009 & 0.00003 & N.D. & 0.00006 \\
\hline & $o, p^{\prime}-\mathrm{DDD}$ & 44 & N.D. & N.D. & N.D. & N.D. & N.D. \\
\hline & $p, p^{\prime}-\mathrm{DDD}$ & 58 & N.D. & N.D. & N.D. & N.D. & N.D. \\
\hline & Total & 4,980 & 0.00014 & 0.00125 & 0.00011 & 0.00006 & 0.00038 \\
\hline \multicolumn{2}{|r|}{ Aldrin } & 5,000 & N.A. * & N.D. & N.D. & N.D. & N.D. \\
\hline \multirow[t]{5}{*}{$\mathrm{BHC}$} & $\alpha$ & N.A. ※ & N.A. ※ & 0.00034 & 0.031 & 0.0024 & 0.00045 \\
\hline & $\beta$ & N.A. * & N.A. ※ & 0.00005 & 0.0075 & 0.00037 & 0.00011 \\
\hline & $\gamma$ & N.A. * & N.A. ※ & 0.00014 & 0.017 & 0.00048 & N.D. \\
\hline & $\delta$ & N.A. ※ & N.A. ※ & 0.00006 & 0.0095 & 0.00018 & 0.00021 \\
\hline & Total & N.A. * & N.A. ※ & 0.00060 & 0.065 & 0.00342 & 0.00097 \\
\hline
\end{tabular}

※.A.: not analysis

S-5 では 99.99999\%の值が予想される。異性体別にみて も, BHC (Total) と同様に酸素量の増加に伴ら分解率の 上昇がみられた（Fig. 10）。このことにより，十分な酸素 濃度によって BHC は高い分解率を示すことがわかった。 しかし，一方でこのことはBHC（Total）はDDT（Total） やアルドリンよりも二次燃焼炉での酸素濃度の影響を受 け易く，酸素濃度が低下した場合は除去率が低下するこ とを示している。よって BHC（Total）を処理する場合 は，二次燃焼内の酸素濃度を注意してモニタリングする ことが運転管理上重要な要素となる。全体除去率では, 二次燃焼炉での低減効果が最も低值であった Run S-3 で も $99.999 \%$ 以上を示しており，加熱炉の温度を $700^{\circ} \mathrm{C}$ に した場合ではより高い除去率が期待される。

以上本研究により, DDT (Total), アルドリン, BHC （Total）は間接的に加熱を行い，気化したガスを二次燃 焼することによって廃農薬から分解除去することが可能 であり，その加熱条件は加熱炬で $600^{\circ} \mathrm{C}$ 以上，二次燃焼 炉で $1,100^{\circ} \mathrm{C}$ であれば $99.999 \%$ の除去率を期待できるこ とが，明らかとなった。

\section{4. 結言}

POPs に関連する廃農薬の加熱無害化処理条件を理解 するために，3 種の廃農薬を用いた基礎実験を実施した。 対象とした物質は, 国内で廃農薬としての埋設量が多い

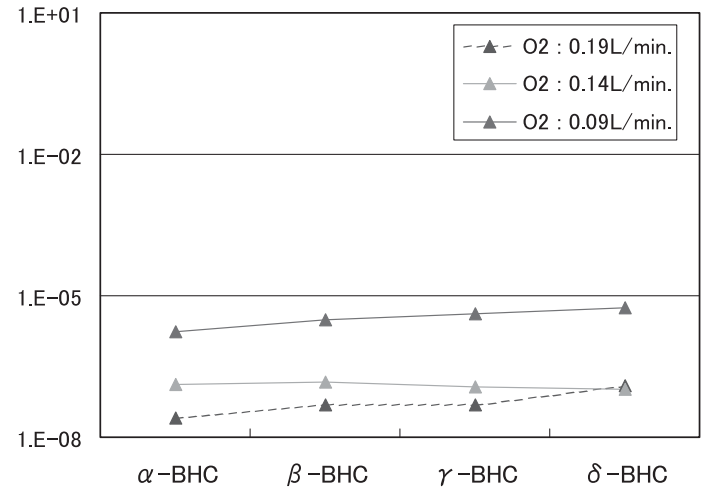

Fig. 10 A ratio of trapped BHC-isomers for pre-heated sample of each Run

DDT 含有農薬のメオバール D 粉剤とアルドリン粉剂, BHC 粒剂を用いた。「熱的特性試験」に扔いて対象物の 気化温度を中心に調査した結果, BHC 粒剂はメオバール $\mathrm{D}$, アルドリン粉剤に比べて気化温度が低く, かつ気化 終了温度が高いため，3 種の中では最も気化（脱着）困 難であった。また気化のみの加熱過程では酸素量の有無 に関係なく 3 種の物質は気化して抢り，実際の処理装置 を想定した場合, 加熱炉内へ十分な空気を送らない状態, すなわち酸素欠乏状態でも気化に影響を及ぼさないこと が分かった。

「加熱試験」では, 加熱温度と残存率および加熱時に発 
生する排ガスへの移行率に注目して調査した。3 種の廃 農薬を混合した試料を用いて加熱試験を行ったところ, 窒素雾囲気下での加熱により気化したガスから DDE 異 性体の増加がみられ，アルドリンは $600^{\circ} \mathrm{C}$ 程度の加熱に よって約 9 割が分解していた。BHC（Total）は加熱に よってほとんど気化したが，アルドリンやDDT（Total） は分解が起こらず，ほぼ全量がガス側へ移行していた。

「二次燃焼試験」では, 加熱処理で発生する排ガスを二 次燃焼炉で燃焼処理した際の対象物質の挙動について調 查した。DDT (Total), アルドリン, BHC（Total）は全 ての物質に沶いて $1,100^{\circ} \mathrm{C} て ゙ の 二$ 次燃焼により高い分解 率が認められた。しかしながら BHC（Total）は他の2 種 と異なった傾向がみられ, 加熱中の酸素濃度が分解に大 きく寄与して扣り, 酸素濃度が減少するにつれて除去率 も低下する傾向がみられた。よって BHC (Total) の処理 では酸素濃度のモニタリングが重要であること考えられ た。

本研究結果から POPs 関連廃農薬の DDT, アルドリン, BHC の混合処理を行ら場合, 最も分解が困難な物質は BHC であり, BHC の処理条件を満足すれば他の 2 種も 効果的に分解できることが示唆された。また気化 (脱着) を目的にした加熱炉と気化したガスを高温燃焼する目的 の二次燃焼炉を組み合わせたシステムによって高い除去 率を得ることができ, システムとして成立することが実 証された。

\section{5. 謝辞}

本研究を行うにあたり, 実験のご指導, ご助言を頂い た元日立造船（株）技術研究所技師長の長屋喜一博士な らびに愛媛大学沿岸環境科学研究センターの Annamalai Subramanian 教授に謝意を表する。

\section{References}

1) Kankyosho Kankyohokenbu: POPs (Zanryusei yukiosenbussitu), p. 1 (2004)

2) H. Iwata, S. Tanabe, K. Ueda, R. Tatsukawa: Environmental Science and Technology, 29, pp. 792-801 (1995)

3) Norinsuisansho seisankyoku: Maisetunouyaku no jittai chousa ni tuite, p. 1 (2002)

4) K. Ueda, S. Iwamoto, S. Umemura, K. Nagaya, H. Iwata, S. Tanabe: Journal of Environmental Chemistry, 15 (2), pp. 311-320 (2005)

5) K. Ueda, S. Hamano, A. Fukatsu, S. Umemura: Study of themal treatment for DXNs contaminated sediments by indirect heating process, $12^{\text {th }}$ Symposium on Environmental Chemistry Programs and Abstracts, pp. 424-425 (2003)

6) K. Ueda, S. Hamano, A. Fukatsu, T. Yasuda, A. Hirotsune, S. Umemura: Study of thermal treatment of dioxincontaminated soil by the indirect heating process, $23^{\text {rd }}$ International Symposium on Halogenated Environmental Organic Pollutants and POPs, 63, pp. 300-303 (2003)

7) Kankyosho kankyokanrikyoku: Maisetunouyaku kussaku tou zantei manual kaiteiban, pp. 1-3 (2005) 